\title{
Sérgio com Lima: um encontro inusitado em meio aos modernismos
}

Sérgio Meets Lima: An Unlikely Encounter Within Modernisms

Lilia Moritz Schwarcz ${ }^{\star}$

Pedro Meira Monteiro ${ }^{* *}$

\section{Resumo}

Partindo do encontro entre Lima Barreto e Sérgio Buarque de Holanda, em 1922, no Rio de Janeiro, recuperamos debates estéticos e políticos da Primeira República, evitando qualquer cisão rígida entre modernistas e não modernistas. Relações de classe, escolas literárias, o espaço urbano e os valores públicos, assim como os dilemas da democracia numa República percebida por ambos como oligárquica, são temas por meio dos quais tentamos aproximar os dois autores, sem deixar de lado suas diferenças. A reflexão posterior de Sérgio Buarque, incluindo a crítica literária e a primeira edição de Raízes do Brasil, é analisada a partir de eixos que tornam Lima Barreto um contraponto para compreender a desconfiança diante de valores republicanos nunca concluídos - tema que atravessa a ficção de um, e a reflexão histórica do outro.

Palavras-chave: Sérgio Buarque de Holanda; Lima Barreto; modernismos; República.

\section{Abstract}

Taking as our departure point the meeting between Lima Barreto and Sérgio Buarque de Holanda in 1922 in Rio de Janeiro, we analyze aesthetic and political debates held during the so-called First Republic (1889-1930). To do so, we avoid any artificial divide between modernists and non-modernists. Some of the topics covered in this article are: class relations, literary trends, urban spaces and public values, and the dilemma faced by a democracy that both authors saw as inherently oligarchical. We also focus on Buarque de Holanda's criticism in the first (1936) edition of Roots of Brazil, and we analyze pieces of literary criticism he published much later. The encounter of the two intellectuals allows us to better understand how they were both skeptical about republican values, which they felt had never prevailed in Brazil. Such a skepticism crosses their work, whether it's fictional or historiographic.

Keywords: Sérgio Buarque de Holanda; Lima Barreto; Modernisms; Republic.

\footnotetext{
* Departamento de Antropologia, FFLCH, Universidade de São Paulo (USP). São Paulo, SP, Brasil. lili. schwarcz@gmail.com

** Department of Spanish and Portuguese, Princeton University. Princeton, NJ, USA. pmeira@ princeton.edu
} 
O objetivo e o objeto deste artigo são um tanto paradoxais, especialmente num dossiê dedicado a Raízes do Brasil, de Sérgio Buarque de Holanda, lançado em 1936 e que merece uma reflexão ampla neste momento em que comemora 80 anos de publicação. Resolvemos enfrentar a obra e seu autor de um ângulo que, se não é novo, pode soar original. Retomamos o contexto dos anos 1920, marcados por todo tipo de incerteza em relação ao regime republicano, e que inaugurava uma agenda de modernismos, no plural. Era tempo de refazer tradições, repensar a história, duvidar do presente e alimentar incertezas em relação ao futuro. Nesse panorama irrequieto, Sérgio Buarque e Lima Barreto iam virando personagens importantes. O primeiro ainda um principiante na crítica, mas já um pensador do Brasil. O segundo, autor que se entendia como militante e crítico, fora da convenção: da Academia, das elites, e da República das Letras que então se formava. A crítica tratou de distanciar Sérgio de Lima como se representassem mundos opostos. A recepção futura apostou suas fichas nas reservas de Sérgio Buarque em relação a uma literatura de fundo realista, que teria em Lima Barreto seu representante. Neste artigo, arriscamos aproximações e distanciamentos, exploramos ambiguidades, incertezas divididas e afinidades compartilhadas.

\section{LADOS OPOSTOS, LADOS CONVEXOS}

Em 1922, com 20 anos de idade, Sérgio Buarque morava no Rio de Janeiro, onde estudava para ser advogado e de onde se correspondia com Mário de Andrade, que o designara representante de Klaxon, a revista dos modernistas paulistas, na então capital federal. Em 20 de julho daquele ano, Sérgio contava, entusiasmado, que o terceiro número da revista vendera bem, sobretudo considerando "a quase frieza com que foram recebidos os dois primeiros números”. O diligente jovem relata então a Mário, pouco mais velho e já reconhecido como um dos líderes do movimento, que encaminhara exemplares da revista aos principais jornais cariocas. É quando o nome de Lima Barreto surge, meio obliquamente, quase como um adendo ao mapa da grande imprensa carioca: "Além disso dei um número ao Lima Barreto a fim de que escrevesse qualquer coisa na Careta, elogio ou ataque, de modo a despertar atenção" (Monteiro, 2012, p.50).

Lima Barreto, àquela altura, já era bastante conhecido nos meios cariocas. Era autor de romances como Recordações do escrivão Isaías Caminha, Numa e 
a ninfa, Triste fim de Policarpo Quaresma, e no final do ano de 1921 publicara, pela editora de Monteiro Lobato, Vida e morte do escrivão Gonzaga de Sá. Era figura carimbada na cena literária carioca e não fazia parte da Academia Brasileira de Letras. Na verdade, tentara por três vezes entrar na instituição, sempre sem sucesso. Na última, desanimado, desistiu antes do final do pleito.

Lima também gozava da fama de "rebelde". Avesso ao formalismo parnasiano, vinculava-se às novas causas sociais, sobretudo dos mais humildes. $\mathrm{O}$ cronista circulava nos ambientes boêmios, era leitor dos russos e das vanguardas europeias, assinante de revistas francesas, e tinha uma verve crítica que poderia até mesmo agradar ao grupo paulistano. Enfim, juntando dois mais dois, era possível entender a conta de somar que Sérgio Buarque fizera ao entregar pessoalmente a revista a Lima Barreto. Mas ao que tudo indica o resultado da soma deu cinco e não quatro.

Klaxon, e com ela a aventura dos "modernos" paulistas, de fato atrairia a atenção de Lima Barreto, embora ela viesse na forma de um ataque, em $A$ Careta de julho de 1922:

São Paulo tem a virtude de descobrir o mel do pau em ninho de coruja. De quando em quando, ele nos manda umas novidades velhas de quarenta anos. Agora por intermédio do meu simpático amigo Sérgio Buarque de Holanda, quer nos impingir como descoberta dele, São Paulo, o tal de "futurismo" ... Recebi, e agradeço, uma revista de São Paulo que se chama Klaxon. Em começo, pensei que se tratasse de uma revista de propaganda de alguma marca de automóveis americanos. (Boaventura, 2008, p.327-328)

Depois de desfazer de Marinetti e dos jovens de São Paulo, Lima recua e tenta selar a paz: "O que há de azedume neste artiguete não representa nenhuma hostilidade aos moços que fundaram a Klaxon; mas sim, a manifestação da minha sincera antipatia contra o grotesco 'futurismo', que no fundo não é senão brutalidade, grosseria e escatologia, sobretudo esta" (ibidem, p.328). Mas a provocação pegou forte nos jovens, que não aceitaram a pecha de futuristas. $\mathrm{Na}$ Klaxon seguinte sairia um comentário na última página, devolvendo tudo no mesmo tom: "Na Careta (22 de julho) confunde ainda o espírito de atualidade da Klaxon com o futurismo italiano um snr. Lima Barreto. Desbarretamo-nos, imensamente gratos, ao ataque do clarividente. Mas não é por causa da estocada que estamos gratos. Esta apenas nos permitiu sorrisos de ironias" (Klaxon, n.4, ago. 1922, p.17). 
O estilo era de salto alto e de desfaçatez diante da crítica de Lima. Não apenas o desautorizavam, como ironizavam a prática de leitura do carioca:

Snr. Lima, como seu artigo "não representa Klaxon" amigavelmente tomamos a liberdade de lhe dar um conselho: Não deixe mais que os rapazes paulistas vão buscar no Rio edições da Nouvelle Revue, que, apesar de numeradas e valiosíssimas pelo conteúdo, são jogadas como inúteis embaixo das bem providas mesas das livrarias cariocas. Não deixe também que as obras de Apollinaire, Cendrars, Epstein, que a Livraria Leite Ribeiro de há uns tempos para cá (dezembro, não é?) começou a receber, sejam adquiridas por dinheiros paulistas. Compre esses livros, Snr. Lima, compre esses livros! (ibidem)

As provocações vão subindo de tom, com os mais novos tentando se diferenciar de um "passado" associado ao Rio de Janeiro. A nota anônima de Klaxon é, possivelmente, do próprio Mário de Andrade, que no número anterior da revista respondera a um artigo ácido publicado por Agripino Grieco no Mundo Literário, reagindo com a mesma cena dos livros jogados embaixo da mesa de uma livraria carioca.

Não há como saber se Lima Barreto leu as notas de Klaxon, até porque ele morreria logo mais, em novembro de 1922. Mas os "moços" respondiam com arrogância ao comentário do escritor carioca e devolviam na mesma moeda que era o estilo de Lima: ironizar, atacar e depois tentar alisar e aliviar a crítica. Dessa vez, não houve alívio; ao contrário, ficou evidente o atrito entre os grupos literários.

\section{OUtros Muitos LADOS}

Pode ser ainda que o nome de Lima Barreto se vinculasse, para os articulistas de Klaxon, a Monteiro Lobato, que em 1917 escrevera sua resenha severa sobre a exposição de Anita Malfatti, atingindo aquele que seria, nos anos seguintes, o grupo dos modernistas de São Paulo. Se não há como saber se Lima leu a crítica de Lobato, publicada antes de estabelecerem contato pessoal, podemos no entanto imaginar que esse tipo de opinião acerca dos "modernos" não fosse tão incomum, no final da década de 1910 e começo da seguinte. Levaria algum tempo para que os nomes cariocas do grupo modernista fossem mais conhecidos. Villa-Lobos, por exemplo, tocava violoncelo num cabaré, e Manuel Bandeira só publicaria Carnaval em 1919. 
Sérgio Buarque de Holanda era um jovem que, ainda em São Paulo, no início do anos 1920, frequentara o seleto grupo de rapazes que se reuniam na confeitaria Fazzolli e no escritório de advocacia do pai de Guilherme de Almeida, onde Sérgio Milliet, Rubens Borba de Moraes e Tácito de Almeida, entre outros, se juntavam para discutir as novas tendências da arte e da literatura europeia. Ocasionalmente, passavam por ali Oswald de Andrade e Mário de Andrade, assim como Di Cavalcanti, que viera do Rio de Janeiro (Barbosa, 1988, passim).

Conquanto polêmico, Monteiro Lobato foi figura importante e talvez um elo oculto de relações que passavam não apenas por simpatias e antipatias estéticas, mas também pela questão editorial. Sérgio publicaria, na Revista do Brasil então editada por Lobato, em 1920, uma resenha do Ariel de José Enrique Rodó, num tom elitista muito distante da nuance que marcaria seus textos seguintes, inclusive em suas incursões pela imprensa do Rio de Janeiro, em que ele apresentaria os modernistas paulistas ao público leitor carioca, em artigos na revista ilustrada Fon-Fon, encomendados por Gustavo Barroso.

Ainda na Fon-Fon, Sérgio declararia, em fevereiro de 1922, quando acontecia em São Paulo a Semana de Arte Moderna, que cabia a Manuel Bandeira o papel de "iniciador do movimento modernista". Afinal, escreve o jovem articulista, o autor de Carnaval dera "o primeiro golpe na poesia idiota da época em que ainda se usava o guarda-chuva, que é positivamente uma prova evidente do mau gosto estético dos nossos avós" (Holanda, 1996, p.144). O tom polêmico continuaria, assim como a ideia de que a arte deveria libertar-se de seu aspecto utilitário, abrindo-se à experimentação poética. No entanto, a vida de um jovem que não pertencia às classes abastadas exigia vínculos de trabalho: além de escrever para vários jornais, Sérgio trabalhava como tradutor e datilógrafo dos telegramas em inglês da agência de notícias Havas.

Daqueles que iam sendo nomeados modernistas, Lima conhecia Graça Aranha, que publicara Canaã em 1902, era membro da Academia Brasileira de Letras e andava muito pelos circuitos literários cariocas. Embora o pensamento de Graça Aranha não agradasse Lima, tampouco agradaria totalmente os modernistas paulistas, embora alguns deles cultuassem o autor da Estética da vida, que operava como um mediador entre gerações. Por outro lado, a Semana de Arte Moderna em São Paulo fora abertamente financiada por Paulo Prado, que mais tarde se juntaria a Lobato na direção da Revista do Brasil. Ele, a essas alturas, era interlocutor e financista do grupo, convivendo com gente 
como Alcântara Machado, Yan de Almeida Prado e, mais tarde, Blaise Cendrars.

Já Lima Barreto, em seus artigos, desancara a "plutocracia paulista", em especial Antonio Prado, que seria chamado de "açougueiro" num artigo em $O$ Debate, de setembro de 1917, intitulado "Sobre a carestia". Estamos quase no pós-guerra, e Lima acusa o fazendeiro de explorar os brasileiros ao aumentar o preço da carne. Nesse mesmo texto, Graça Aranha é definido como "seu caixeiro-viajante", talvez por conta de seu papel como embaixador, talvez por sua amizade com Antonio Prado. O fato é que o escritor carioca se opunha à República, identificando-a à ganância dos paulistas e de seus representantes literários. Tudo entrava no mesmo balaio, o que mostra como Lima parecia predisposto a não gostar da atividades dos "moços", que associava de um lado à burguesia do café; de outro, ao acadêmico Graça Aranha, e ao que chamava de uma visão copiada e inapropriada do "futurismo". Tampouco Klaxon mereceu a simpatia que o escritor costumava dedicar aos iniciantes.

É assim que Lima Barreto recebe a revista das mãos do jovem Sérgio Buarque de Holanda: percebendo em seus articulistas meros "imitadores de Marinetti” e, no modernismo, uma cópia fácil do futurismo. Se tivesse lido com calma, notaria que eles negavam serem adeptos do movimento italiano, muito embora o próprio Sérgio, como vimos, tivesse apresentado o movimento aos leitores cariocas como "futurista”, pecha de que Mário de Andrade fugiria, mas que os demais aceitaram durante algum tempo.

Para os modernistas paulistas, algo estaria escapando aos olhos cansados dos atrasados cariocas. E os "dinheiros paulistas", na expressão - de gosto duvidoso - dirigida a Lima Barreto em Klaxon, vinham para comprar o que era deixado de lado, como se a visão "moderna" fosse, ela apenas, capaz de compreender o que tinha valor naqueles anos que eram "frementes" também no Rio de Janeiro. De uma forma ou outra, o "futurismo" atribuído aos modernistas paulistas era o estopim da guerra, embora a questão fosse muito mais ampla que o simples mapeamento do gosto literário das duas facções.

A turma de Klaxon, de um lado, e Lima Barreto, de outro, seriam posteriormente percebidos pela crítica literária como polos opostos de uma equação. Por muito tempo, jogou-se para baixo do tapete aquilo que se opunha ao modernismo paulista, abrigando toda uma produção sob o rótulo do "pré-modernismo". Diferentemente, procuramos pensar na complexidade de um campo literário que não admitia cisões rígidas, e que se conformava de maneira relacional, contrastiva e transitória. Talvez, no arco tenso que "opunha" Klaxon a 
Lima Barreto, Sérgio Buarque funcionasse como um mediador, aquele que leva mensagens, mais ou menos consciente de seu conteúdo explosivo, e verga (um pouco) para os dois lados, pendendo ao fim para os modernistas.

Não se trata de imaginar que Sérgio e Lima estivessem de lados opostos, mas tampouco se trata de supor que algo mais profundo os unisse. O termo "futurista" mobilizava corações e mentes, e levaria ainda algum tempo até que se tornasse anátema para vários dos modernistas brasileiros, ou mesmo para que fosse satirizado no samba de Noel Rosa e Lamartine Babo, "A. B. Surdo", de 1931, em que o "futurista" não é senão um mau pagante. Para recuperar a ambivalência do futurismo, bastaria lembrar o tour sul-americano de Marinetti em 1926, quando Manuel Bandeira o ouviu extasiado no Rio de Janeiro, enquanto Mário de Andrade o evitou, irritado com o "cagaço confraternizador" do pensador italiano que, para o autor da Pauliceia desvairada, não passava, àquela altura, de um "delegado do fascismo" (Moraes, 2001, p.296).

\section{O ESGotamento Do REALISMO E A POSE JUVENIL}

Voltando ao tempo em que Lima Barreto e Sérgio Buarque se conheceram, vale a pena lembrar mais um autor: Enéas Ferraz, protegido de Lima e testemunha de sua decadência física e espiritual. No início de 1922, Ferraz publicara a História de João Crispim, que logo mereceu uma nota ambivalente de Sérgio no Rio-Jornal. Nela, o jovem paulistano destacava a qualidade "carioca” da obra. É aí que surge, novamente, o nome de Lima Barreto:

O romance de Ferraz é uma obra caracteristicamente carioca. É mesmo uma das poucas que podem figurar neste caso. Ao lado dele só conheço no gênero dos nossos romances mais recentes a obra de Lima Barreto. O Rio já criou os seus tipos particulares, como todas as grandes cidades. Assim como soube criar o cafajeste, personagem genuinamente carioca, criou também o filósofo vagabundo, espécie de Diógenes Bárbaro, tipo interessantíssimo e não aproveitado ainda em obras de ficção antes de João Crispim. A figura central do romance foi traçada com rigorosa observação. (Holanda, 1996, p.145-147)

Entretanto, Sérgio chamaria atenção para o esgotamento do "realismo" que presidia a narrativa de Enéas Ferraz: "creio perfeitamente razoável a pergunta dos expressionistas alemães: a verdade está aqui: para que repeti-la?”. A discussão em torno do "realismo" dirigia-se, subliminarmente, à obra do 
próprio Lima Barreto. O incômodo com o marco realista da literatura era questão pungente para o jovem articulista. Ao mesmo tempo, o debate sobre vagabundos geniais que perambulavam pelas grandes cidades também o mobilizava, porque lhe interessava a potência errática desses sujeitos "desviantes", que podiam contrabalançar os anseios modernizadores da elite bem-pensante, dos arquitetos das políticas públicas racionais e dos discursos higienistas, que previam que apenas “corpos saudáveis” poderiam ensejar mentes sãs. Já Lima era o boêmio que fora internado no manicômio por duas vezes e hostilizava abertamente a sociabilidade literária bem comportada do Rio de Janeiro.

Em depoimento de 1976 a Antonio Arnoni Prado, um outro Sérgio Buarque, já assentado na carreira, recordou seu primeiro encontro com Lima Barreto. Mais tarde, em clima de reminiscências, Arnoni escreveria uma tocante e imaginária "carta" destinada a Mário de Andrade, em que narra a cena, supostamente ouvida durante a entrevista:

Sérgio foi bater na livraria Schettino, um maço de exemplares da Klaxon debaixo do braço. Manhã bem cedo, a livraria fechada, quem vem lhe abrir a porta, imagine a surpresa!, é um Lima Barreto maldormido e estremunhado que vai logo amaldiçoando a luz do sol e a chegada do primeiro cliente. Como passasse uma temporada na rua largado à vida boêmia, o livreiro Schettino o abrigava ali entre os livros, acomodando-o num pequeno estrado atrás do balcão principal. (Prado, 1993, p.13-14)

Imaginária ou não, a cena é reveladora. A despeito das diferenças profundas que os separavam, algo houve entre Lima e Sérgio que parece ter chegado perto de torná-los comparsas - ou "confrades", como o escritor carioca se referia aos colegas escritores em suas cartas. Em comum havia também a descrença diante da irrealização dos valores republicanos, e a percepção de que a República podia ser, no fim das contas, uma grande farsa. Talvez essa visão crítica da República pudesse tê-los tornado próximos, mas a morte prematura de Lima em 1922 fez que essa possível amizade não durasse mais que alguns meses, tomados aliás por bastante ruído.

É curioso imaginar como um jovem franzino e elegante, afetado na sua sofisticação literária, podia relacionar-se ao "maldormido" Lima Barreto. A afetação do jovem paulistano era conhecida na cidade letrada carioca. Logo mais, no mês de abril de 1922, um artigo assinado por "João Crispim" (pseudônimo de Lima) aparece em A Careta. Nele, o escritor carioca repreende com 
ironia, embora sem sombra do azedume posterior, o "futurismo". Dessa vez é a um genérico "Sérgio" que se dirigem as críticas:

O meu amigo Sérgio, crítico literário, hóspede de casa de pensão, estudante de Direito, escritor de pró-labores a $20 \$ 000$ e, mais do que tudo isso, um futurista de imensa imaginação, vai publicar uma revista intitulada Vida Literária. A notícia é positivamente agradável. Espera-se todo o sucesso... Mas Sérgio, que usa um pedaço de monóculo no olho direito, sempre que me topa aí pelas esquinas, atravessa-me o caminho com um gesto alto e discreto, ajeita no olho o seu brunhido cristal e entra a definir copiosamente o que seja o futurismo. Entretanto, eu vou cometer aqui uma imperdoável irreverência para com esses moços que ajeitam os seus monóculos parados às esquinas, o braço em arco, pálidos, faces encovadas, a mão branca e longa nos acenando gestos nervosos - com a afirmação de que, a respeito do futurismo, me fez o meu vendeiro, o Sr. Manuel, português do Minho, homem de tamancos, proprietário abastado e, no fundo, muito bom coração ...

- Aí é que está a coisa! O sinhoiri João está a vieiri que o homem não é um literato e, vai daí, cada vez que lhe mando cobrar a conta, insulta-se, torna-se fulo, diz que espere, pois que ele é um futurista. E faz assim com o padeiro, com o açougueiro e até com o sinhoiri farmacêutico, que eu soube! (Boaventura, 2008, p.387-389)

Conquanto houvesse quase um abismo social entre os dois, não resta dúvida de que aquele jovem de monóculo era mesmo Sérgio Buarque de Holanda. É conhecida a descrição de Manuel Bandeira, num artigo publicado em 1952 no Diário Carioca, em que o poeta relembra a figura excêntrica do jovem amigo caminhando pelas ruas do centro do Rio, naqueles idos de 1921 ou 1922:

A classe de Sérgio! Foi a primeira qualidade que me chamou a atenção para ele há uns trinta anos. Nunca me esqueci de sua figura certo dia em pleno largo da Carioca, com um livro debaixo do braço, e no olho direito o monóculo que o obrigava a um ar de seriedade. Naquele tempo não fazia senão ler. Estava sempre com o nariz metido num livro ou numa revista - nos bondes, nos cafés, nas livrarias. Tanta eterna leitura me fazia recear que Sérgio soçobrasse num cerebralismo cuja única utilidade seria ensinar a escritores europeus de passagem pelo Rio a existência, desconhecida por eles, de livros e revistas de seus respectivos países. Sérgio talvez não tivesse lido ainda a Ilíada ou a Divina Comédia, mas lia todas as novidades das 
leituras francesa, inglesa, alemã, italiana e espanhola. Sérgio não soçobrou: curou-se do cerebralismo caindo na farra. (Bandeira, 1987, p.90)

Lima e Sérgio quem sabe poderiam vir a ser colegas de "farra", mas uma farra talvez um pouco diversa daqueles primeiros encontros que vieram a compor uma espécie de mitologia inaugural do modernismo na capital federal, quando, a acreditarmos na memória transbordante de Gilberto Freyre, ele e Sérgio tomavam inumeráveis chopes ao som de Pixinguinha, Donga e Patrício Teixeira, nos bares do centro do Rio (Freyre, 1987, p.117). A turma de Lima era outra, também da boêmia, embora composta por vários escritores que ficaram fora do cânone literário, mais voltados para uma literatura "social". Se os dois tivessem sido colegas de noitada, talvez Lima atenuaria a ojeriza que desenvolveu diante dos modernistas, e Sérgio talvez acelerasse a perda da pose "cerebral". O carioca também, quem sabe, abriria mão de sua avaliação severa, ao ver nos modernistas meros "bovaristas", "copiadores" dos modelos estrangeiros. Isso não se sabe. O fato é que o monóculo de Sérgio Buarque logo viraria motivo de sarro até mesmo entre os amigos. Em carta enviada de Campos do Jordão naquele mesmo ano, Ribeiro Couto perguntaria ao jovem Sérgio: "Que tem feito você além de espantar os caixeiros da Livraria Leite Ribeiro com o seu monóculo adolescente?”. ${ }^{1}$

Para além dos dados anedóticos, havia um orgulho, um sentimento de diferença que o jovem de monóculo perderia, como corretamente supôs Manuel Bandeira. Muito mais tarde, aliás, num artigo publicado em 1941, Sérgio reveria a resposta irada do grupo modernista a Lima, que os tomara por "futuristas": "o azedume ... veio antes do lado dos klaxistas, indignados com a confusão. O criador de Isaías Caminha fora até moderado e mesmo maliciosamente simpático quando se referiu ao pessoal de Klaxon. Todo o seu mau humor reservara-o para o italiano" (Holanda, 1996, p.345).

O fato é que as respostas de Klaxon às reações da imprensa carioca baseavam-se em grande medida no monitoramento de Sérgio Buarque, que comunicava a Mário de Andrade as manifestações dos “passadistas”. Ao mesmo tempo, ao ler o texto de Lima de maio de 1922, ficamos sabendo que àquela altura o futuro historiador concebia uma revista própria, que se chamaria Vida literária. Esse talvez fosse o embrião de Estética, que Sérgio Buarque viria a fundar e dirigir, entre 1924 e 1925, em parceria com seu dileto amigo Prudente de Moraes, neto. Essa, contudo, é outra história. 


\section{QUE FAZER COM A DANADA DA REALIDADE?}

Existem muitas diferenças entre Lima e Sérgio. Em primeiro lugar no que se refere ao realismo como gênero literário. Se Lima elege esse modelo e o vê como única maneira de realizar uma literatura engajada no Brasil, Sérgio se mostrou crítico à escola, e destilou sua oposição na resenha mais tardia que fez ao romance inacabado Clara dos Anjos, escrita em 1948 e publicada como prefácio à edição póstuma de 1956. Em sua análise, Sérgio bate forte e encontra, no apego à realidade, o fruto da falta de imaginação. Procurando dar conta de toda a obra do carioca, e não apenas do livro em questão, a resenha retomava a vida de Lima, para insistir na tecla de como o autor não se separava de seu próprio destino, o que o limitaria em sua arte. Bem a seu estilo, que era também o de Lima, Sérgio condena, para logo reconhecer em sua obra "uma das mais admiráveis da nossa prosa de ficção” (Holanda, 2012, p.35).

Tal qual uma "confissão de amarguras íntimas", a obra de Lima constituiria, para o Sérgio que escrevia em 1948 - mais de 25 anos após a morte do autor carioca -, um convite para se discutir a abordagem mais eficaz da própria literatura. Já escaldado quanto aos excessos do New Criticism anglo-americano, que tratara de relativizar a importância dos dados biográficos para a análise do texto ficcional, Sérgio ao mesmo tempo admitia e não admitia a importância da vida torturada de Lima para a compreensão de sua obra, pensando que a "refundição estética" dos problemas pessoais não teria se dado de modo satisfatório nos seus livros: "os problemas íntimos que o autor viveu intensamente e procurou muitas vezes resolver através da criação literária não foram integralmente absorvidos e nela ainda perduram em carne e osso como corpo estranho" (Holanda, 2012, p.36-37).

Levando tal interpretação a seu limite lógico, Lima não passaria de uma sombra de suas influências: "Antes de abordar francamente um dos aspectos do problema do mestiço, o que faria em Clara dos Anjos, já o deixa transparecer em vários escritos". Sérgio cita, por exemplo, a famosa passagem em que "um caixeiro atende mal Isaías Caminha que lhe pede troco, ao passo que recebe prazenteiramente a reclamação de outro freguês, este alourado, e não mestiço como ele, Isaías”, marcando "um contraste suficiente para transtornar suas relações com o mundo que o cerca". E conclui: "Há nessa humilhação, sem dúvida, o eco de muitas outras que o romancista padeceu pessoalmente e registrou em seu diário íntimo ainda inédito ... Suscetibilidades que parecem 
ter se agravado nos anos seguintes ao primeiro acesso de loucura de seu pai, ocorrido em 1903" (Holanda, 2012, p.36).

Sérgio passa a listar então todos os momentos em que Lima se refere a "seu estigma", como na passagem em que volta da Ilha do Governador, onde fora pagar uma dívida do pai, e encontra um desafeto que passeava "como me desafiando", diz ele, ao lado da esposa. "O idiota me persegue", diz ainda, e “tocou-me na tecla sensível, não há negá-lo. Vê, seu negro. Você me pode vencer nos concursos, mas nas mulheres não. Poderás arranjar uma, mesmo branca como a minha, mas não desse talho aristocrático.” Lembra também como em outra ocasião, quando encontra uma esquadra americana de visita ao Rio de Janeiro, notou que, na prancha de embarque, a ninguém pediam convite, mas a ele pediram. E conclui: “É triste não ser branco". E no Ministério da Guerra, onde servia como amanuense, alguém o tomou por contínuo. Isso lhe sucedeu por três vezes, e precisava de "muito sangue-frio para que não desmentisse com azedume" (Holanda, 2012, p.37).

A despeito de nuançar sua análise, afirmando ser absurdo "procurar nesses desajustamentos a explicação para toda a arte de Lima Barreto”, Sérgio defende existir aí "alguma coisa de seu sabor". Em oposição a "Machado de Assis, que saído do Morro do Livramento procuraria os bairros da classe média e abastada, este homem nascido nas Laranjeiras, que se distinguiu nos estudos de Humanidades e nos concursos, que um dia sonhou tornar-se engenheiro, que no fim da vida ainda se gabava de saber geometria contra os que o acusavam de não saber escrever bem, procurou deliberadamente a feiura e a tristeza dos bairros pobres, o avesso de Botafogo e de Petrópolis" (Holanda, 2012, p.38).

Como que buscando explicar Lima pelo tempo que lhe coube, Sérgio diz que esse era seu "orgulho, daquela espécie de orgulho que o faria referir-se ao próprio desmazelo de hábitos e indumentária, dizendo que era essa a sua elegância e a sua pose”. Astrojildo Pereira, em livro aliás citado por Sérgio Buarque, diria que Lima Barreto pertencia à categoria dos "romancistas que mais se confessam". Para aquele crítico, "os seus romances estão cheios de alusões e indicações de natureza autobiográfica - alusões e indicações quase sempre feitas abertamente, com um mínimo de disfarce, às vezes até sem disfarce algum" (Pereira, 1957, p.76).

Mas o que era elogio para Astrojildo, Sérgio transformaria em crítica:

É desnecessária uma excessiva argúcia para sentir que essa noção da arte, da Arte, como forma de compensação e de redenção, era própria de Lima Barreto, e 
que a ênfase convencional com que a exprime neste caso é talvez uma tênue caricatura, não um disfarce. Sua suscetibilidade às pequeninas mas reiteradas humilhações constitui motivo de revolta contra os outros, mas sobretudo contra a própria condição. E de revolta que não quer traduzir-se abertamente nos escritos destinados ao grande público, mas de que o diário íntimo ainda inédito exprime em mais de um passo. (Holanda, 2012, p.39)

Se aceitamos a visão de Sérgio, diríamos então que Lima Barreto "não conseguiu forças para vencer, ou sutileza para esconder, à maneira de Machado, o estigma que o humilhava" (ibidem). Além de poder expressar-se num texto não de todo bem-acabado, o desejo de denúncia social explicaria ainda por que Lima tantas vezes dissera desprezar a obra de Machado de Assis, considerando-a inferior à de Aluísio Azevedo. Enquanto a obra de Lima se aproximaria perigosamente do libelo, a de Machado, segundo Sérgio Buarque, era muito mais uma forma de "evasão e refúgio" da realidade - o que, para o crítico paulistano, traduzia-se em valor positivo, por manter o texto longe do "realismo" de que ele tanto desconfiava. Em Lima Barreto, em suma, não teria se desenvolvido plenamente uma "arte feita de vigilância, de reserva e de tato", como em Machado de Assis.

No entanto, há diferenças sociais importantes entre os autores, que complicam ainda mais a discussão. Referimo-nos a marcadores sociais de diferença como raça, região, geração e classe social, que vincam as perspectivas de cada um. Lima trazia sempre à frente sua condição marginal: morava nos subúrbios, era negro, relativamente pobre, e falava em nome de uma geração boêmia que começa a ser vista como "do passado". Não se pode pensar aqui em causa e efeito, até porque em literatura não há continuidade ou descontinuidade absolutas com o contexto. Mas não há como negar que havia aí divisão de escolas e de influências literárias. Lima aconselhava sempre a seus discípulos que lessem Taine, Spencer, Renan e autores russos: "Dostoievski, Tolstoi, Turguêneff, um pouco de Górki, mas, sobretudo, o Dostoievski da Casa dos Mortos e do Crime e Castigo" (Barreto, 1956, p.98). Esses eram os "russos" de sua predileção, que o inspiraram quando ele estava no hospício.

Lima ia defendendo, diante das novas gerações, a importância da literatura social em que tanto acreditava, prometendo a seus correspondentes exemplares de Kropótkine, de Hamon, de Reclus e outros. Recomendava também "o maluco do Comte e o Spencer, Introdução à Ciência Social e a Moral entre os diferentes povos" (ibidem). Na discussão de como a "realidade" deveria se 
transfigurar na ficção, tornava-se impossível contornar a questão racial. Para Lima esse era um tema central e inadiável, e lhe parecia preciso boicotar países como os Estados Unidos, por conta de sua política de segregação no Sul. A questão apareceria mais obliquamente na obra de Sérgio Buarque: em 1972, quando da publicação de Do Império à República, a resistência à Abolição forneceria um dos fios para a compreensão do recrudescimento do espírito oligárquico no Brasil no momento em que o país ensaiava tornar-se uma República, quando a crise do Império se fazia cada vez mais clara.

A crítica radical à República aparece de forma diversa na obra dos dois autores. Mas, se regressamos ao ano de 1922, quando eles se conheceram, havia em ambos um pequeno flerte com a Monarquia. Não com uma Monarquia real, mas com uma forma simbólica de oposição à Primeira República, que prometera inclusão e ia devolvendo exclusão social. Lima, em seus romances, contos e crônicas, batia pesado no governo, acusando jornalistas, políticos e literatos de compartilharem a vida de "negócios", e da falta de compromisso com o país. Já Sérgio, em seu primeiro artigo, publicado em A Cigarra em 1920, quando tinha apenas 17 anos de idade, saúda o Imperador e engrossa o coro dos que pediam a revogação do banimento da família imperial e o consequente regresso, ao Brasil, dos restos mortais de D. Pedro II (Costa, 2011, p.3-7). No entanto, mesmo quando seu monarquismo de juventude já passara, ele se manteria aferrado à ideia de que a República não entregara o que prometera. Talvez aí, na desconfiança diante da promessa falha da República, encontre-se a chave para compreender como, em 1936, quando a editora José Olympio publica Raízes do Brasil em sua nova coleção Documentos Brasileiros, dirigida por Gilberto Freyre, Sérgio Buarque esposa uma ideia que fora também central para Lima Barreto: a crítica ao "bovarismo" republicano.

Ambos compartilhariam a denúncia do fascínio que exerciam as ideias vindas do exterior, e essa terrível tendência à imitação que assolava os brasileiros. Para Lima, o bovarismo era "essa mania de se querer diferente do que se é". O conceito, forjado a partir da obra célebre de Flaubert, fora retirado de Jules de Gaultier (1858-1942), filósofo e jornalista do Mercure de France, periódico no qual, provavelmente, Lima conheceu a obra desse autor. A teoria girava em torno do poder da ilusão; acerca da capacidade humana de se conceber a partir do que não se é. Para Gaultier, os homens eram eternos mentirosos e produziam sentidos a partir da ilusão que criavam para si. E o modelo não se aplicava apenas aos indivíduos; poderia referir-se também a um grupo, 
uma sociedade, ou uma nação. Tratava-se, pois, de um tratado da "ilusão universal" (Buvik, 2006, passim).

Seguindo a mesma linha, Lima desfaria dos edifícios modernos, do football, das danças importadas, do feminismo (a despeito de ser contra a violência doméstica), todos considerados por ele sinais da obsessão com o que vinha de fora, sem combinação alguma com o que haveria dentro do país, em sua própria formação histórica. Aqui vemos como a crítica ao artificialismo das soluções republicanas, tão forte em Raízes do Brasil, encontra na obra de Lima Barreto um de seus muitos antecedentes, ainda que pouco conhecido.

Os dois autores professariam, em momentos distintos, sua crítica ao Brasil oligárquico dos grandes latifúndios, com suas hostes de desvalidos. Lima Barreto criou uma galeria de personagens para mostrar, por vários ângulos, como o país era feito de heróis muitas vezes vencidos, empobrecidos, que se tornavam nostálgicos, quando não céticos. Ao invés do patriotismo, era a crítica à nação que parecia fazer sentido nessa literatura que o próprio Lima chamava, propositalmente, de militante (Barreto, 1921, p.58-59).

Se o caráter militante de Sérgio Buarque não era necessariamente tão evidente, ainda assim a crítica ao "bovarismo" atravessa Raízes do Brasil, ensaio que pode ser lido como uma grande pergunta sobre o que se podia erguer sobre um cimento mole e inacabado, que parecia inadequado à tarefa de construção nacional perseguida por tantos ensaístas dos anos 1920 e 1930. A discussão sobre o "homem cordial", que se tornaria célebre a partir de então, terminava num gigantesco impasse:

A vida íntima do brasileiro não é bastante coesa, nem bastante disciplinada para envolver e dominar toda a personalidade, ajustando-a como uma peça consciente ao ambiente social. Ele é livre, pois, para se abandonar a todo o repertório de ideias e de gestos que encontra em seu meio, ainda quando obedeçam ao mais rigoroso formalismo. (Holanda, 1936, p.110)

$\mathrm{Na}$ discussão da cordialidade, preparava-se o terreno para a crítica do "bovarismo", que expressa a destreza em fingir-se perfeito e fazer de conta que não há, sob a perfeição de fachada, uma vida inconfessável que foge às aparências e aos contornos nítidos do ideal. Além do mais, joga para o outro, para o Estado, as mazelas da imperfeição. O retrato do Brasil que então se desenhava pela pena de Sérgio não era nada edificante. Surge então o pendor, típico no Brasil, para as fórmulas prontas e um discreto horror à realidade: "um amor 
pronunciado pelas formas fixas e pelas leis gerais, que circunscrevem a realidade complexa e difícil dentro do âmbito dos nossos desejos, é dos aspectos mais constantes do caráter brasileiro" (Holanda, 1936, p.118).

Sérgio Buarque volta um espelho pouco lisonjeiro aos seus compatriotas. Seu alvo eram os valores positivistas que fundaram a República, em tudo refratários à "fluidez e à mobilidade da vida". A democracia, segundo fórmula que se tornaria bastante conhecida, "foi sempre um lamentável mal-entendido" no Brasil. Ao fim de tudo, o "convívio das ideias e especulações" era apenas uma forma de "evasão da realidade", uma maneira espelhada e projetiva de olhar para a nossa própria realidade sem encará-la de fato. A artilharia se voltava para o artificialismo e a idealização do país, que era imaginado diverso do que é. Em Raízes do Brasil, sugere-se um romantismo que não mexera em nada, e que apenas ensinara a passar ileso diante da dura realidade do país:

Apenas não nos devem iludir as aparências, a ponto de nos fazerem ver nos movimentos de depressão e de exaltação que oferece essa literatura romântica, muito mais do que uma superfetação na vida brasileira. Tornando possível a criação de um mundo fora do mundo, $\mathrm{o}$ amor às letras não tardou em instituir um derivativo cômodo para o horror à realidade, à nossa realidade. Não reagiu contra ela, de uma reação sã e fecunda, não tratou de corrigi-la ou dominá-la; esqueceu-a, simplesmente, ou detestou-a, provocando desencantos precoces e ilusões de maturidade. Machado de Assis foi a flor dessa planta de estufa. (Holanda, 1936, p.125)

A equação é complexa: Machado de Assis é um acidente interessante nesse cenário de constantes negações e intermináveis fugas, porque foi capaz de introduzir a realidade em sua ficção, mas não de forma direta. Já Lima Barreto, se nos fiarmos na crítica a Clara dos Anjos, escrita por Sérgio em 1948, teria deixado que os seus problemas, e as questões sociais explicitadas por eles, aparecessem demasiado, sem que fossem devidamente filtrados pela ficção, restando como ossos e galhos num terreno mal lavrado. ${ }^{2}$

O problema apontado por Sérgio não é a presença da realidade na ficção, mas sim o que ele julgava ser sua aparição imediata, sem uma cuidadosa elaboração literária prévia e um amplo trabalho da imaginação. Como se, em Raízes do Brasil, e depois na crítica a Clara dos Anjos, fosse recolocada "a pergunta dos expressionistas alemães”, que Sérgio lembrara na década de 1920: “a verdade está aqui: para que repeti-la?". Mais que simples gesto juvenil do vanguardista, tratava-se, já naquela época, de uma simpatia profunda pelos 
debates da arte moderna na Europa. Sérgio, aliás, seria um dos primeiros e mais agudos entusiastas do surrealismo, escrevendo em 1925 um artigo em que afirmava, em tom de manifesto, que diante do "desenho rígido e anguloso das coisas", mais que nunca "toda arte poética há de ser principalmente - por quase nada eu diria apenas - uma declaração dos direitos do Sonho" (Holanda, 1996, p.215).

Mas é Machado de Assis quem parece desempenhar um papel intermediário importante para Sérgio Buarque: nem o realismo exacerbado de Lima Barreto, nem a completa fuga da realidade dos românticos. Se por um lado essa avaliação é clara para o crítico literário, por outro lado a primeira edição de Raízes do Brasil carrega um elogio latente às soluções políticas orgânicas, que tomam em conta a realidade do país. Na sua revisão da literatura brasileira, a ficção parecia necessitar maturação, ao mesmo tempo que a interpretação da história nacional levava a inquirir as raízes do país, o que por sua vez conduziria a uma relação complexa com a realidade, que se traduziria na forma de um ensaio que jamais fecha o círculo da explicação. Estranha divisão de áreas, que devia atormentar o crítico literário tanto quanto o historiador social. Talvez pudéssemos arriscar uma fórmula e sugerir que, para um como para o outro, e ainda que em graus diversos, chegar ao núcleo do real somente seria possível se estabelecêssemos uma relação oblíqua com a realidade.

No plano político, para Sérgio, enquanto prevalecessem as relações sociais estabelecidas no meio rural, patriarcal e escravista, a influência da metrópole não se desfaria de todo, e tal herança apenas se desbarataria com o advento do mundo urbano, que ia aos poucos promovendo a ruína da ordem antiga. Até lá, o ensaísta é cristalino: "o americano ainda é interiormente inexistente" (Holanda, 1936, p.137). Já Lima ia na contramão da urbanização, a qual, segundo ele, só trouxera mais miséria e o oposto do bem-estar.

Mas o pensamento de Sérgio Buarque pendula diante dessa inexistência interior do americano, diante da incapacidade de encontrar sua seiva para bem aproveitá-la, ou seja, diante do vazio que um discurso de fachada mal recobre, com suas ideias girando em falso, fora de seu eixo e lugar. Aí surge a pergunta sobre a literatura como uma possibilidade de vencer aquela distância. Curiosamente, o caminho não será, para Sérgio, o "realismo" de Lima Barreto. Mesmo assim, a aposta numa solução de encontro, em algum plano profundo - tanto literário quanto político - entre as ideias e a realidade, era desejável e parecia urgente. Em sua obra de intérprete do Brasil, em diálogo com tantas outras do período, era exatamente esse encontro que Sérgio buscava, sugerindo 
a necessidade de olhar de frente os impasses que então se apresentavam. O grande dilema era que a "realidade" nacional, em 1936, ia apontando para a matriz personalista da política, e as ideias liberais, conquanto bonitas e reluzentes, nada ou pouco diziam dessa mesma realidade. Havia entre a política e a sociedade um gap, um vazio incômodo, semelhante àquele que o debate no campo da literatura procurava também iluminar.

\section{RAÍZES DO BRASIL: UMA RELAÇÃO COMPLEXA COM A REALIDADE ${ }^{3}$}

Quando foi publicado em 1936, Raízes do Brasil continha ainda uma dose importante de desconfiança em relação às grandes teses liberais, as quais vinham sendo verdadeiramente testadas no período entre guerras, trazendo ao primeiro plano do debate a questão da adequação entre ideias e realidade.

O desconforto patente de Sérgio Buarque com o caudillismo hispano-americano não chegava a fazê-lo acreditar que uma visão mais impessoal da política pudesse derrotar o personalismo que atravessava o espaço público latino-americano, e brasileiro em particular. O personalismo, em suma, não seria derrotado por uma democracia liberal, porque o pacto político que ela pressupunha não se ajustava aos traços mais profundos da história brasileira. Para muitos leitores isso pareceria, nos idos de 1936, uma verdade insofismável, e Raízes do Brasil era mais um livro, ao lado de Casa-grande \& senzala, de Gilberto Freyre, ou mesmo ao lado da obra autoritária de Oliveira Viana, a postular a origem ibérica da civilização no Brasil e imaginar os brasileiros distantes, ou talvez protegidos, das "ilusões da mitologia liberal". O pressuposto também é que essa era quase uma segunda natureza, que não se suplantaria mecanicamente com a modernização. Ao menos essa é a tese geral que se pode ler nas versões mais recentes do livro de Sérgio Buarque - ou, como se lê na primeira edição de Raízes do Brasil: estávamos ainda longe das muitas ilusões "fraudulentas" da mitologia liberal.

Sintomaticamente, o adjetivo "fraudulentas" some, na releitura radical que o historiador faz de seu próprio livro, nas muitas revisões que promove em suas edições seguintes - leitura radical que seria corroborada por Antonio Candido, a partir de 1969, quando se publica seu célebre prefácio a Raízes do Brasil. Acontece que após a Segunda Guerra Mundial as coisas haviam mudado. Qualquer suspeita em relação ao pacto liberal seria agora colocada, ela mesma, sob suspeita. A primeira edição de Raízes do Brasil andava ainda 
repleta de flertes com uma noção mais sólida do Estado, especialmente no seu último capítulo. Isto é, de um lado, em chave hegeliana, o Estado era compreendido como uma forma abstrata e superior da sociedade, uma transcendência; mas, de outro lado, buscava-se uma solução - em sentido quase químico, senão alquímico - que tornasse essa forma superior mais próxima e integrada à realidade, numa relação entre Estado e sociedade que se poderia chamar, finalmente, de orgânica.

Não é necessário grande esforço de imaginação para perceber o que podia significar a defesa de um Estado sem fissuras no imediato pós-guerra. Esquematizando, é possível dizer que um Estado que complementasse as "necessidades específicas" da sociedade, como se lê já na primeira edição de Raízes do Brasil, poderia resultar num Estado forte, enquanto a política liberal pretendia, ao contrário, que se discutisse democraticamente quais seriam essas "necessidades específicas" a cada local, e as respostas múltiplas a demandas de direitos plurais. Trata-se sempre, em suma, de uma questão de adequação à realidade. Mas qual realidade? Aquela que nos irmanava à história de outros Estados considerados modernos, ou aquela que recuperava nosso passado marcado pelo latifúndio, pela mão de obra escrava, pelo passado colonial e pela origem ibérica? Eis a questão insolúvel na literatura e na imaginação social do período.

O imbróglio se torna ainda maior quando pensamos que as tais "necessidades específicas" do país, como se lê em Raízes do Brasil, eram por natureza indefiníveis. Afinal, se fossem facilmente definíveis, a própria política representativa e democrática se tornaria supérflua. Quem precisa de política se um líder é capaz, por exemplo, de traçar um diagnóstico perfeito das mazelas nacionais, oferecendo a cura definitiva de todos os nossos males? Levando o esquema a seu limite lógico, uma vez que os traços nacionais fossem identificados e tomados em conta pelo governante - e ademais, entendidos como imutáveis pois marcados por traços culturais persistentes -, a política já não seria mais necessária - ao menos não no seu sentido liberal, como um palco em que diferentes forças lutam pelo controle do Estado e pelo direcionamento de suas políticas públicas. Por isso, o modelo democrático, que visa o debate entre diferenças a partir de projetos de cidadania entre iguais, talvez parecesse até deslocado, no momento em que o livro de Sérgio Buarque era publicado. O que estava em questão, quando se publicou Raízes do Brasil pela primeira vez, era a crise e a relativa impotência do pacto representativo do liberalismo, quando se erguia o modelo de um Estado forte, de um lado, e se gestava o populismo, 
de outro. Crise, aliás, que mal ousamos discutir em nossa contemporaneidade, talvez porque hoje, passadas umas tantas décadas da experiência dos totalitarismos, saibamos bem o que significa apostar todas as fichas num Estado sem fissuras.

É verdade que Sérgio Buarque estaria preocupado, desde 1936, em criticar o modelo de um Estado forte, à esquerda ou à direita, como aliás fica claro na nota, na primeira edição do livro, em que ele se contrapõe a Otávio de Faria, um dos grandes baluartes do pensamento autoritário no Brasil. Mas, ao mesmo tempo, o Estado deveria ser, se seguirmos a argumentação em Raízes do Brasil, uma forma que viesse ao encontro das "necessidades específicas" da sociedade, de seu "ritmo espontâneo". O argumento parece indicar uma cadência própria do corpo social, que o bom político seria capaz de ouvir. Mas o argumento pode ser falacioso, porque se por um lado justifica a singularidade de cada país no concerto das nações, por outro justifica e naturaliza um destino nacional, como se as sociedades tivessem comportamentos que fossem da ordem da natureza, e não explicados por meio da cultura, da história e da política.

É certo que Sérgio não iria tão longe, nem chegaria a propor um curto-circuito que pudesse atar o líder ao povo. Mas não há como esquecer que o livro é escrito na aurora dos populismos na América Latina, quando a representação era um problema espinhoso e dramático, e a emergência do poder simbólico do líder colocava o carisma no centro do debate político. O leitor de Raízes do Brasil encontrará esta imagem ao final do ensaio: como "compor um todo perfeito de partes tão antagônicas"? A pergunta convida a pensar nas pluralidades de um país de tamanho e lógica continentais, mas também nos impasses da representação política, diante dos quais nem o liberalismo nem o populismo ofereciam respostas totalmente satisfatórias.

Mas seria apenas na década de 1930 que tais discussões se esclareceriam, anos após a morte de Lima Barreto. Em 1922, quando Lima e Sérgio se conheceram fugazmente, nem um nem outro possuía os instrumentos adequados para formular os impasses da questão política de forma tão clara e tão paradoxal. Tinham, é claro, elementos para desconfiar dos ganhos incontestes do regime republicano; ao menos aquele que lhes fora dado conhecer.

Já em Raízes do Brasil, escrito quando Sérgio havia se desencantado com o modernismo e passara quase 2 anos na Alemanha, o "bovarismo" seria enfrentado de maneira mais direta, e a crítica ao desejo de fugir da realidade - e de produzir novos espelhos para se mirar - seria levada a suas últimas consequências. Mesmo assim, não era claro, nem àquela altura, que a solução fosse 
a aposta incondicional no desvendamento da realidade. Ensaiando-se historiador, em seu livro de estreia Sérgio percebia que entre as ideias e o real se interpõem as representações, as fantasias, os mitos, as simbologias herdadas e refeitas, os costumes persistentes, as heranças relidas no presente e as expressões confusas que sempre recobrem a ação humana. Entre as ideias e a realidade, colocava-se também uma expressão que ganharia fôlego décadas depois, mas que àquela altura mal havia aterrissado na imaginação dos intelectuais brasileiros: a ideologia. Ou talvez, nos termos simples e pungentes de Lima Barreto, tratava-se dessa "mania de se querer diferente do que se é".

Se não é necessário ler Raízes do Brasil a partir desse diálogo com Lima Barreto, é no mínimo desafiador buscar entender como o livro conversa com uma agenda dos anos 1920, compartilhada entre autores que a recepção futura viria a definir como pertencentes a searas opostas e distintas. Distintas, sem dúvida, mas a seu jeito assemelhadas, talvez muito mais próximas do que sugere um olhar superficial, ou mais perto do que permite ver o pouco que sabemos sobre o encontro entre os dois autores. Refazer esses diálogos, rejeitando dicotomias fáceis e paradas no tempo, pode ajudar a refletir sobre ambos em seus momentos de produção, mas também para além deles. Ajuda também a retomar a crítica para torná-la, ela própria, uma forma de reflexão. Por fim, é uma maneira de entender as histórias do pensamento nacional como um campo aberto a novas perguntas que muitas vezes dirigimos aos mesmos autores e aos mesmos textos, mas a partir de demandas, inquietações e tempos distintos.

\section{REFERÊNCIAS}

BANDEIRA, Manuel. Sergio, o anticafajeste. Revista do Brasil, n.6, p.90-91, jul. 1987. BARBOSA, Francisco de Assis. Verdes anos de Sérgio Buarque de Holanda. Ensaio sobre sua formação intelectual até Raízes do Brasil. In: SÉRGIO Buarque de Holanda: vida e obra. São Paulo: Secretaria de Estado da Cultura/Arquivo do Estado; Universidade de São Paulo/IEB, 1988. p.27-54.

BARRETO, Afonso Henriques de Lima. O destino da literatura. Revista Souza Cruz, Rio de Janeiro, out./nov. 1921, p.58-59.

Correspondência ativa e passiva. vol. 2. São Paulo: Brasiliense, 1956.

BOAVENTURA, Maria Eugênia (Org.) 22 por 22: a Semana de Arte Moderna vista pelos seus contemporâneos. São Paulo: Edusp, 2008.

BUVIK, Per. Le principe bovaryque. In GAULTIER, J. Le Bovarysme: essai sur le pouvoir d'imaginer. Paris: Presses Universitaires de France, 2006. 
COSTA, Marcos (Org.) Sérgio Buarque de Holanda: escritos coligidos, livro I - 19201949. São Paulo: Ed. Unesp, 2011.

FREYRE, Gilberto. Sergio, mestre dos mestres. Revista do Brasil, n.6, p.134-141, 1987. HOLANDA, Sérgio B. de. O espírito e a letra. vol. 1. Org. Antonio Arnoni Prado. São Paulo: Companhia das Letras, 1996. . Prefácio. In: BARRETO, Afonso Henriques de L. Clara dos Anjos. São Paulo: Penguin Classics Companhia das Letras, 2012. p.35-48. . Raízes do Brasil. Rio de Janeiro: Livr. J. Olympio, 1936. . Raízes do Brasil. Edição crítica, org. Pedro Meira Monteiro e Lilia Moritz Schwarcz. São Paulo: Companhia das Letras, 2016.

MONTEIRO, Pedro Meira (Org.) Mário de Andrade e Sérgio Buarque de Holanda: correspondência. São Paulo: Companhia das Letras; Edusp; IEB, 2012.

MORAES, Marcos A. de (Org.) Correspondência Mário de Andrade \& Manuel Bandeira. São Paulo: Edusp; IEB, 2001.

PEREIRA, Astrojildo. Interpretações. Rio de Janeiro: Eb, 1957.

PRADO, Antonio A. Você entra no episódio que vou contar. In: LUCAS, Fábio (Org.) Cartas a Mário de Andrade. Rio de Janeiro: Nova Fronteira, 1993.

\section{NOTAS}

${ }^{1}$ Arquivo Privado Sérgio Buarque de Holanda, Siarq-Unicamp, Cp 16 P5.

${ }^{2}$ No entanto, em conselhos que dá a Jaime Adour da Câmara em carta de fevereiro de 1919, Lima Barreto ajuíza: "arredonde mais", não deixe passar "as costelas, o esterno"; "deixe as leituras mais transfiguradas por um pensamento de moço e seu" (BARRETO, 1956, p.98).

${ }^{3}$ Organizando recentemente a edição crítica de Raízes do Brasil, evidenciou-se para nós que as notáveis alterações feitas entre as três primeiras edições do livro (1936, 1948 e 1956) podiam revelar uma obra em constante transformação, espécie de testemunho de como o autor negociava sinuosamente com algumas de suas ideias de juventude. Retomamos aqui ideias desenvolvidas no nosso prefácio àquela edição. Cf. HOLANDA, 2016.

Artigo recebido em 5 de julho de 2016. Aprovado em 26 de agosto de 2016. 